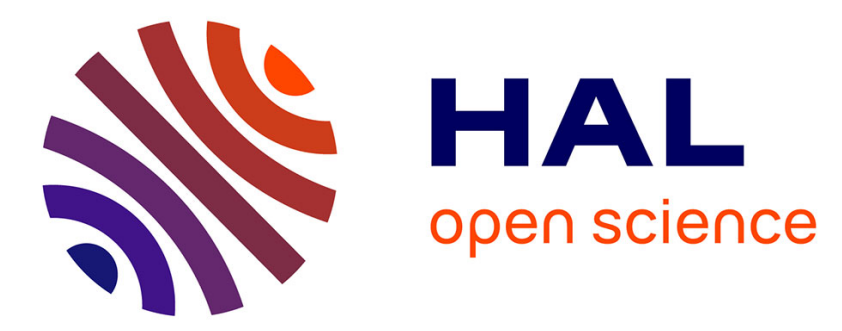

\title{
Impacts of product, store and retailer perceptions on consumers' relationship to terroir store brand
}

\author{
Jérôme Lacoeuilhe, Didier Louis, Cindy Lombart
}

\section{To cite this version:}

Jérôme Lacoeuilhe, Didier Louis, Cindy Lombart. Impacts of product, store and retailer perceptions on consumers' relationship to terroir store brand. Journal of Retailing and Consumer Services, 2017, 39, pp.43-53. 10.1016/j.jretconser.2017.07.002 . hal-01672920

\section{HAL Id: hal-01672920 \\ https://hal.science/hal-01672920}

Submitted on 5 Jan 2018

HAL is a multi-disciplinary open access archive for the deposit and dissemination of scientific research documents, whether they are published or not. The documents may come from teaching and research institutions in France or abroad, or from public or private research centers.
L'archive ouverte pluridisciplinaire HAL, est destinée au dépôt et à la diffusion de documents scientifiques de niveau recherche, publiés ou non, émanant des établissements d'enseignement et de recherche français ou étrangers, des laboratoires publics ou privés. 


\title{
Impacts of product, store and retailer perceptions on consumers' relationship to terroir store brand
}

\author{
Jérôme Lacœuilhe ${ }^{\mathrm{a}}$, Didier Louis ${ }^{\mathrm{b}}$, Cindy Lombart ${ }^{\mathrm{c}, *}$

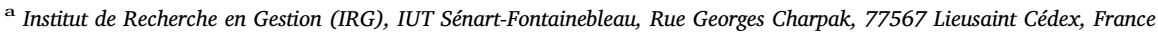 \\ b Laboratoire d'Economie, et de Management (LEMNA), IUT de Saint Nazaire, 58 Rue Michel-Ange, BP 420, 44600 Saint Nazaire, France \\ ${ }^{c}$ Research Center in Marketing \& Distribution In Situ, AUDENCIA Business School, 8 route de la Jonelière, BP 31222, 44312 Nantes Cedex 3, France
}

\section{A R T I C L E I N F O}

\section{Keywords:}

Store brand

Terroir

Attachment

Loyalty

Authenticity

Image

Trust

\begin{abstract}
A B S T R A C T
This research shows that consumers' relationship to terroir store brand, measured through attachment and two facets of brand loyalty (attitudinal and behavioral) is respectively influenced by their perceptions of the product, retailer and store. More specifically, the perceived authenticity of the products of the terroir store brand and its perceived value have a positive and significant influence on the attachment and behavioral loyalty of the regular buyers of this store brand and a positive and significant influence on the attachment of its occasional buyers. Trust in the retailer has a positive and significant impact on the behavioral loyalty of the regular buyers of this terroir store brand while perceived image of the store has only a positive and significant impact on the attitudinal loyalty of its occasional buyers.
\end{abstract}

\section{Introduction}

In France, after more than a decade of growth, store brands' (SB) market share began to stagnate in 2009; a decline followed. According to Nielsen, between 2014 and 2015, the market value of store brands fell from $28.8 \%$ to $27.7 \%$. This trend continued in 2016 , with a $0.8 \%$ decrease for SBs, compared with a gain of $+2.2 \%$ for national brands (NB). However, this variation is not homogeneous regarding the different types of positioning strategies related to the concept of SB. Whereas so-called standard store brands declined $(-1.0 \%)$, economy store brands plunged much more sharply $(-9.9 \%)$, while third-generation SBs that integrate terroir and organic products rose by $4.4 \%$ and $11.5 \%$ respectively. ${ }^{1}$

These differences in performance may be explained by the nature of the positionings adopted by SBs. Standard store brands undoubtedly suffer from their "me-too product" policy. Mirroring the quality level of national brands products, their price level has become much less attractive. The Loi de Modernization de l'Economie (Modernization of the Economy Act, or LME) contributed to significantly reduce the SB-NB price differential, by $10-15$ points. Store brands labeled as terroir, organic or third-generation have not faced this handicap. Their niche positioning shelters them from direct comparison with national brands. Their ability to respond to prevailing consumption logics manifested by the authentic (return to sources: local, terroir and traditions) and citizen consumption (organic, quality line) explains the growth of their market share.

To date, works on consumers' relationships with SBs have mainly examined standard store brands (Binninger, 2007; Diallo et al., 2013; Belaid and Lacœuilhe, 2015). This is partly explained by their weight and seniority on the market. Third-generation SBs are more recent, particular those designated as terroir. The first such product appeared only in 1996, with "Reflets de France." Starting in the early 2000s, most food retailers developed this type of offer to highlight culinary traditions and authentic know-how (Beylier et al., 2012; Lenglet et al., 2015). Even if this type of brand is less prominent than standard SBs, it nonetheless contributes to sales at the stores, to recruiting customers and building customers' loyalty to the stores and the retailer while cultivating their images. In parallel, for over 10 years diverse marketing research has examined terroir products. Studies in this field have notably focused on consumers' perceptions of their characteristics (Aurier et al., 2004; Fort and Fort, 2006; Spielmann and Gélinas-Chebat, 2012) and on the interaction between attitude toward terroir products and consumers' relationships with the territory in terms of regional belonging, regional ethnocentrism and attachment to a place (Aurier and Fort, 2005; Debenedetti, 2014; Charton-Vachet and Lombart, 2015).

Despite this economic vigor and the keen interest in the theme of terroir products (Aurier et al., 2004; Fort and Fort, 2006; Spielmann and Gélinas-Chebat, 2012), few studies have explored the relationship

\footnotetext{
* Corresponding author.

E-mail addresses: jerome.lacoeuilhe@u-pec.fr (J. Lacœuilhe), didier.louis@univ-nantes.fr (D. Louis), clombart@audencia.com (C. Lombart).

${ }^{1}$ Nielsen Trends, P7, 2016.
} 
that consumers maintain with terroir SBs. This topic indeed seems worth investigating. This relationship may be influenced not only by consumers' perceptions of this type of offer, but also by variables linked to their vision of the store and of the retailer. Contrary to other terroir products, this type of brand is endorsed directly (e.g., "U-Saveurs") or indirectly (e.g., "Reflets de France" for Carrefour, "Nos Régions ont du Talent" for Leclerc) by the retailer and its stores. Jara (2009) demonstrated that the brand equity of standard SBs integrates the image of the branded products, the image of in-store service and that of the retailer at the institutional level. Moreover, the relationship that consumers maintain with terroir SBs may be moderated by consumers' profile. Binninger (2007) showed that consumers' buying profile of standard SBs (i.e., uninitiated, captive, unstable and engaged) influences the level of three variables relating to the relationship between consumers and these brands: satisfaction, attitude and loyalty.

Consequently, the present study will focus specifically on terroir SBs and thus complete the literature on this topic (Beylier et al., 2012; Lenglet et al., 2015). It will examine the relationship between consumers and terroir SBs by considering the direct and indirect impacts (through mediation effects) of customers' perceptions of the product, of the store and of the retailer on consumers' attachment and brand loyalty (attitudinal and behavioral). This study will thus provide to academics and practitioners a model highlighting the determinants of the relationship between consumers and terroir store brands. It will also stress the relative importance of these determinants according to their buyers' profile of terroir store brands (i.e., occasional verus regular buyers of terroir SBs).

First, we describe the specific features of terroir SBs. Then, the nature of consumers' relationship with this specific type of SB will be discussed along with the direct and indirect effects of consumers' perceptions of the product, of the store and of the retailer on this relationship. The moderating effect of consumers' profile on the studied relationship will also be considered. Ensuing research hypotheses will be posited. Lastly, the research methodology and results will be presented and the managerial implications and limitations will be discussed.

\section{Conceptual framework}

\subsection{Terroir $S B$ : a very distinct $S B$ !}

In this section, we first introduce the concept of terroir, then we focus on the characteristics of terroir products and finally, we define the subject of this paper, terroir store brands.

The concept of 'terroir', which has no direct translation in English (Lenglet, 2014), has numerous attributes. From a physical point of view, the concept of terroir relies on geographical and geological attributes. From a social point of view, this concept relies on human attributes. From a philosophical point of view, the concept of terroir relies on hedonic and symbolic attributes (Vaudour, 2002; Barham, 2003; Charters, 2006). Charters et al. (2017) define terroir as "a resource based on unique physical origins and shared cultural personification that shape a product's benefits into a meaningful value proposition not possible for products lacking this specific origin".

Considering terroir products, these specific products have two main characteristics: the grounding of the product in a geographical place and the existence of specific representations in consumers' minds related to history, culture and know-how (Aurier et al., 2004; Fort and Fort, 2006). In their synthesis of the scientific literature and of the work of professional organizations on the concept of terroir, Aurier et al. (2004) describe several elements that affirm, to varying degrees, the "terroir" characteristics of a product: the origin of the raw materials, along with the regional or local origin of the recipe or of the expertise, and the history of the company in its terroir. They thus distinguish three main sources of terroir products: reference to the geographic area, time and culture, and know-how. Moreover, terroir products are perceived by consumers as unique, having not reproducible qualities: artisanal, recognizable, qualitative, or different (Spielmann and Gélinas-Chebat, 2012). Consequently, consumers are willing to pay more for consuming such products (Cross et al., 2011).

Considering the works of Beylier et al. (2012) and Lenglet et al. (2015) we define in this research terroir store brands as brands proposed by retailers that encompass several products which refer to attributes like terroir, products' origin, culinary know-how, heritage, traditions and gastronomy. The positioning of terroir SBs is thus different from that of other brands endorsed by retailers. They clearly depart from the original objectives of SBs, which were notably to stand out from national brands in terms of price, and to restore power to retailers in their negotiations with manufacturers. Through their terroir image that conveys the values of quality and authenticity, terroir SBs can develop attachment to themself while building customer loyalty (Spielmann and Charters, 2013).

\subsection{The relationship between consumers and terroir $S B$ : the role of attachment and loyalty}

Attachment is now widely rooted in research on consumer-brand relationships (Thomson et al., 2005; Park et al., 2010). Consumers interact with thousands of objects or brands but only a few may generate attachment. The reference to the theory of attachment in psychology (Bowlby, 1979) indicates the value of this concept. Indeed, the attached individuals are more likely to be engaged, invested in their relationship with a person, an object or a brand and are willing to make sacrifices to maintain it. The works on attachment to people emphasize the emotional nature and strength of the bond that binds them (Bowlby, 1969; Fournier, 1998). This is due to the physical and psychological protection provided by the person to whom we are attached (for example, a young child attached to his mother).

People can also be attached to specific objects (Belk, 1988; Ball and Tasaki, 1992) with the desire to maintain proximity to them. The study of this phenomenon is part of the tradition of research on the expressive function of consumption. The goal of this field of research is to understand the behavior of an individual from the meaning he gives to his possessions (Wallendorf and Arnould, 1988; Belk, 1992; Richins, 1994).

Thomson et al. (2005) and Park et al. (2010) clearly distinguish the concept of attachment from the concept of attitude. Attachment grows over time and is characterized by different interactions with the object or the brand. These interactions create meanings and emotions. Consumers may have favorable attitudes toward a number of brands but these brand may not have significant meanings in their lives. Lasty, being attached to a brand can cause fear and anxiety when the consumer is separated from it. Considering these differences, Lacoeuilhe (2000) defines attachment to a brand as a lasting, unalterable affective relationship that expresses a close psychological relationship with it. This attachment is sustained by two main factors: nostalgic connections generated by the brand and congruence with the self-concept (Fournier, 1998). Through these temporal and symbolic elements, the brand plays a role in defining and maintaining individual identity.

The positioning of terroir SBs refers to attributes like terroir, products' origin, culinary know-how, heritage, traditions and gastronomy (Lenglet et al., 2015). These attributes can feed nostalgia and congruence. More generally, Lenglet et al. (2015) assert that consumption of terroir products corresponds more closely to hedonic and/or symbolic motivations than to utilitarian or functional ones. This seems to justify the importance placed on the affective dimension of the purchasing act and of the consumption of this type of products.

Attachment has very clear consequences on the quality of the stability and sustainability of a relationship because it notably translates individuals' fixation in the choice of brand (Julienne, 2013). Several studies (Lacouilhe, 2000; Thomson et al., 2005) foreground the "predictive" aspect of attachment in commitment and willingness to make financial sacrifices to obtain a particular brand. Commitment to a brand 
is defined as the degree of the consumer's fixation in the relationship with the brand despite obstacles that may alter this relationship (Terrasse, 2006). Attachment is often considered as a measure of marketing effectiveness (Dwyer et al., 1987; Moorman et al., 1992; Morgan and Hunt, 1994). This concept is used by researchers to capture the attitudinal approach toward brand loyalty and is considered as an essential element in the success of a long-term relationship (Gundlach, 1995). It explains why some relationships last while others do not (Geyskens and Steenkamp, 1995). However, commitment is interesting, particularly managerially, only if it predicts repetitive purchasing behavior and hence behavioral loyalty toward the brand. Since the pioneering work of Jacoby and Chesnut (1978), studies on brand loyalty tried to examine both its attitudinal and behavioral facets. The attitudinal approach therefore does not suffice to explain brand loyalty behavior. Specifically, commitment must closely link individuals to their behavior and the associated cognitions (Kiesler, 1971). Based on these findings, the relationship between consumers and terroir SB will be examined in the present study from the perspective of attachment and attitudinal and behavioral loyalty.

The link between consumers' brand attachment and attitudinal loyalty toward the brand, measured by commitment (Lacœuilhe, 2000; Terrasse, 2006), has been demonstrated repeatedly in the literature (Lacouilhe, 2000; Thomson et al., 2005; Louis and Lombart, 2010; Julienne, 2013). The existence of this relationship is one of the major challenges of the theoretical and managerial interest in the notion of attachment because it integrates a new antecedent in a deterministic approach to brand loyalty. Julienne (2013) posits that consumer attachment is also translated by specific behaviors like maintaining proximity with the object or brand in question. Therefore, consumers' brand attachment should be manifested by cumulative purchasing acts and consumption of a particular brand (Julienne, 2013). Consumer attachment to a brand is indeed a determinant of future behavioral intentions toward the brand (Mende et al., 2013). Lastly, since the pioneering work of Jacoby and Chesnut (1978), it is admitted that consumers' repetitive purchasing behavior of a brand can be construed as a manifestation of loyalty to the brand only if it arises from consumers' favorable attitude toward the brand.

Given the findings above, we posit the following hypotheses:

H1. Consumers' attachment to the terroir SB has a positive influence on their attitudinal loyalty toward this brand.

H2. Consumers' attachment to the terroir SB has a positive influence on their behavioral loyalty toward this brand.

H3. Consumers' attitudinal loyalty to the terroir SB has a positive influence on their behavioral loyalty toward this brand.

H4. Consumers' attitudinal loyalty to the terroir SB mediates the relation between consumers' attachment to the terroir SB and consumers' behavioral loyalty toward this brand.

\subsection{Impacts of the perceptions of the product, the store and the retailer on the consumer-terroir SB relationship}

Terroir SBs have a dual characteristic. They project a specific positioning while being endorsed, directly or indirectly, by a retailer and its points of sale. The relationship that consumers may develop with these brands is therefore linked to their perceptions of products and the credibility of their positioning, but are also inferred from their links to the retailer and its stores (Jara, 2009).

\subsubsection{Authenticity and perceived value of terroir $S B$}

As Lenglet et al. (2015) maintain, marketing of terroir products tends to rest on cognitive attributes such as origin, quality and knowhow. Beylier et al. (2012) argue that terroir products offer consumers six important characteristics that create a specific image: irrefutable quality, singularity of the product of origin, expertise in production, a long history, respect for traditions in its preparation and, lastly, a high price commensurate with the guaranteed quality. More globally, consumers consider terroir products to be of better quality, and more natural, traditional and authentic (Aurier et al., 2004). These perceptual elements have encouraged both manufacturers and retailers to affix the term terroir to their respective offers. However, this poses a risk of instrumentalization (Camus, 2004a). Therefore, one of the elements that could capture the credibility of the terroir positioning, and in turn its positive perceptions by consumers, is the concept of perceived authenticity (Camus, 2004a).

Camus (2004a) defines perceived authenticity as a product characteristic that attaches the product to an origin that distinguishes it from other products, that fills a gap or a dissatisfaction, and that is reinforced when the product represents part of the individual's identity. This authenticity is favored by knowledge of the origin, which can be historical, geographic, sociocultural or technical. Perceived authenticity, owing to its connection to temporal, symbolic and identitycreating elements, can thus constitute the first variable that may influence consumers' relationship to terroir SBs. Camus (2004b) also demonstrates that the perceived authenticity of the product has a positive influence on the consequences of attitudinal loyalty, in other words consumers' intention to purchase the product. In the same vein, Spielmann and Charters (2013) indicated that authenticity of terroir products is positively correlated to satisfaction, quality perceptions and purchase intent.

Given the findings above, we posit that:

H5. Perceived authenticity of the terroir SB has a positive influence on consumers' attachment to the brand (a), attitudinal loyalty toward the brand (b), and behavioral loyalty toward the brand (c).

Since this research integrates the links suggested by previous studies between consumers' attachement, attitudinal loyalty and behavioral loyalty (hypotheses 1-3), the following mediating effects must be posited:

H6. Consumers' attachment to the terroir SB mediates the relation between perceived authenticity of the terroir SB and attitudinal loyalty toward the brand (a) and behavioral loyalty toward the brand (b).

H7. Consumers' attachment to the terroir SB and consumers' attitudinal loyalty toward this brand mediates the relation between perceived authenticity of the terroir SB and behavioral loyalty toward the brand.

Terroir SBs, often called third-generation SBs, are characterized by an evolution of the quality of the offer relative to economy store brands and standard store brands. Consumers' attitude toward these first types of SBs is shaped mainly by economic fundamentals (Binninger, 2007). Researchers have affirmed the link between variables like perceived price-quality ratio, sensitivity to economic value, perceived risk, or the smart shopper effect, and consumers' attitude toward standard store brands (Burton et al., 1998; Garretson et al., 2002). For the specific brand type studied in this research, the terroir SB, references regarding the geographic and cultural origin are more salient. Diallo et al. (2013) emphasize the need to question the success of terroir SBs by considering other elements than those mobilized by standard SBs. The objective is thus to detach from the variables connected uniquely to attractiveness in terms of price but also linked to comparisons of quality between manufacturers' brands and standard SBs. Based on these findings, the present research examines, via hypothesis 8 , the impact of perceived authenticity of terroir SBs on their perceived value for consumers.

H8. Perceived authenticity of the terroir SB has a positive influence on its perceived value for consumers.

Perceived value of the brand is considered as the central element in the consumer-brand relationship (Ambroise et al., 2010). It traditionally encompasses two dimensions: utilitarian and hedonic (Babin et al., 
1994; Chaudhuri and Holbrook, 2001). Utilitarian value is related to the economic dimension, the utility of the product and its price-quality ratio. The hedonic dimension refers to more experiential elements like the pleasure of purchasing and its recreational aspect. Depending on the study, the symbolic facet of value is either integrated in the hedonic value or is treated independently (Holbrook and Hirschman, 1982; Park and Young, 1986; Keller, 1993; Ailawadi et al., 2001). The examination of the symbolic dimension in its own right is justified by the fact that it refers to self-expression and thus to the identity-creating role of the brand.

The link between perceived value and attitudinal loyalty has been demonstrated uniquely in the field of services marketing, to our knowledge. Accordingly, Khan (2010) shows that perceived relational value has a significant positive influence on commitment. In contrast, functional value does not have a significant influence on this variable. Other studies have also found a significant positive influence of perceived value on commitment (Luarn and Lin, 2003; Lai, 2015). Lastly, the strong predictive power of value on future behavioral intention has been affirmed several times (Chen and Hu, 2010; Cronin et al., 2000; Duman and Mattila, 2005; Yoon et al., 2010).

Given these studies, we posit that:

H9. Perceived value of the terroir SB has a positive influence on consumers' attachment to the brand (a), attitudinal loyalty toward the brand (b), and behavioral loyalty toward the brand (c).

This study will thus examine the role of perceived value of the terroir SB on consumers' relationship, in parallel with perceived authenticity. Consequently, we posit that

H10. Perceived value of the terroir SB mediates the relation between perceived authenticity of the terroir SB and consumers' attachment to the brand (a), attitudinal loyalty toward the brand (b), and behavioral loyalty toward the brand (c).

Moreover, since this research integrates the links suggested by previous studies between consumers' attachement, attitudinal loyalty and behavioral loyalty (hypotheses $1-3$ ), the following mediating effects must be posited:

H11. Consumers' attachment to the terroir SB mediates the relation between perceived value of the terroir SB and attitudinal loyalty toward the brand (a) and behavioral loyalty toward the brand (b).

H12. Consumers' attachment to the terroir SB and consumers' attitudinal loyalty toward this brand mediates the relation between perceived value of the terroir SB and behavioral loyalty toward the brand.

\subsubsection{Role of the retailer and of the store}

One of the objectives of this study is to measure the combined effects of consumers' perceptions of the product, the store, and the retailer, respectively, on their relationship with terroir SB (Jara, 2009). Contrary to other terroir products, terroir SB products are directly endorsed by a retailer and constitute a form of extension of the point of sale (Diallo et al., 2013). The definition of the store image proposed by Bloemer and de Ruyter (1998) clearly reflects this idea by indicating that store image encompasses consumers' perception of its physical environment, and of its assortment, atmosphere and service quality. Diallo et al. (2013) contend that this image, which includes both functional characteristics and psychological attributes, influences consumers' perceptions of the quality of SBs and their purchasing behavior toward them (Collins-Dodd and Lindley, 2003). Coelho do Vale et al. (2016) identified the image of the store (Liu and Wang, 2008), trust in the retailer (Chaniotakis et al., 2009), and perceptions of the quality price ratio as the main factors that determine loyalty to SBs. Consequently, even if terroir SBs constitute an offer that differs from other store brands endorsed by retailers, their evaluation by consumers is influenced by their perceptions of the store and the retailer.

According to Morgan and Hunt (1994) and Garbarino and Johnson (1999), trust is an enduring attachment factor. This specific relationship has often been demonstrated for trust as a global construct and for one or more of its dimensions (Louis and Lombart, 2010; Magnoni, 2016). Trust has also been cited as an antecedent of commitment that corresponds to a measure of attitudinal loyalty (Morgan and Hunt, 1994; Chaudhuri and Holbrook, 2001; Gilliland and Bello, 2002). The link between trust and commitment indeed represents the end of the relational chain proposed by Aurier and N'Goala (2010), which suggests that positive relations exist between perceived value, followed by cumulative satisfaction, trust and commitment. Given that commitment implies potential vulnerability and uncertainty, consumers will be less committed when trust is not well established. For example, if consumers claim to trust a brand, they resolve their uncertainty by committing to a relationship with the brand. Therefore, consumers' commitment to a brand is a consequence of their trust in it (Gurviez and Korchia, 2002; Lacey, 2007). Several studies have shown a significant positive relationship between trust (considered as a global construct or regarding one or more of its dimensions) and commitment (Chaudhuri and Holbrook, 2001; Gurviez and Korchia, 2002; Louis and Lombart, 2010). Lastly, trust is an antecedent of loyalty. A significant positive influence of trust on loyalty (measured by future behavioral intentions) has been demonstrated (Lin et al., 2011; Stanaland et al., 2011). Hence, the more trust consumers have in SBs, the stronger their intention to purchase their products, particularly organic or fair trade varieties (Pivato et al., 2008; Castaldo et al., 2009).

Given the findings above, we posit the following hypotheses:

H13. Consumers' trust in a retailer has a positive influence on their attachment to the brand (a), attitudinal loyalty toward the brand (b), and behavioral loyalty toward the brand (c).

Moreover, since this research integrates the links suggested by previous studies between consumers' attachement, attitudinal loyalty and behavioral loyalty (hypotheses 1-3), the following mediating effects must be posited:

H14. Consumers' attachment to the terroir SB mediates the relation between trust in the retailer and attitudinal loyalty toward the brand (a) and behavioral loyalty toward the brand (b).

H15. Consumers' attachment to the terroir SB and consumers' attitudinal loyalty toward this brand mediates the relation between trust in the retailer and behavioral loyalty toward the brand.

Furthermore, Liu and Wang (2008) have highlighted the influence of the store image on consumers' attitude regarding SBs. Kaswengi (2013) goes beyond the notion of consumers' attitudes and shows that the store image is a determinant of the brand equity of the SB. Ramaroson and Kaswengi (2013) add that this relationship between the store image, broken down into different dimensions, and the brand equity of the SB is moderated by the type of SB. For example, for the premium SB, "price image" has a negative influence on the brand equity of the SB, whereas "service image" and "access image" have a positive influence on this variable. Overall, both "service image" and "price image" have a significant positive influence on brand equity, whereas "access image" has a negative influence on this variable. Further, brand attachment is a variable that contributes to creating brand equity, similar to trust and commitment (Lacouilhe, 2000). Based on this finding, the store image can affect the brand equity of the SB, specifically attachment to the terroir SB. Jara (2009) maintains that the brand equity of the SB integrates the image of the branded product, the image of service in store and the image of the retailer at the institutional level. Lastly, several recent studies have found that the image of the store influences both consumers' loyalty toward SBs (Beristain and Zorilla, 2011; Coelho do Vale et al., 2016) and their purchase intentions (Bezes, 2013; Diallo et al., 2013). These authors consider the store image as a 


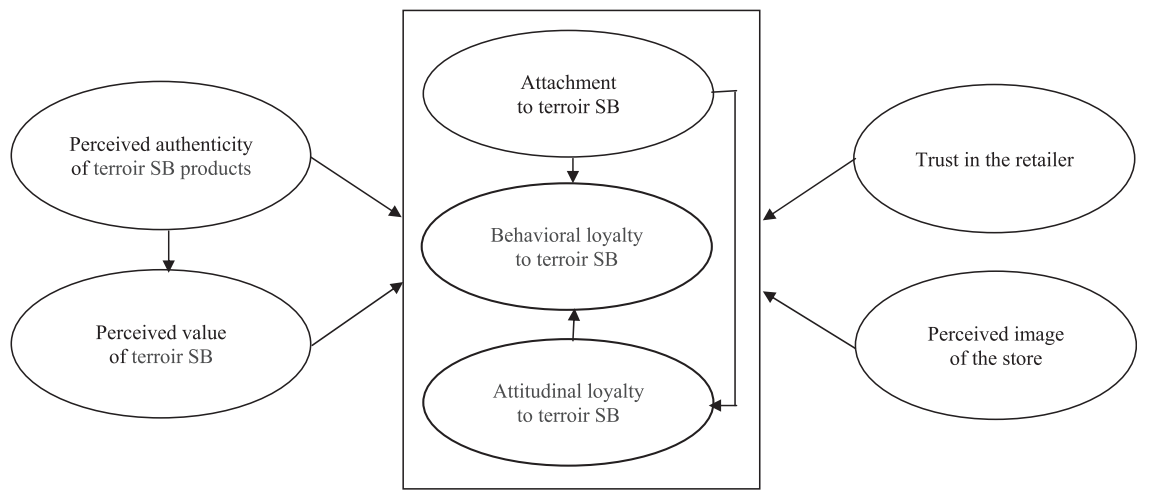

Fig. 1. Research model.

key variable in explaining the performance of SBs.

Based on the findings above, we posit that:

H16. The perceived store image has a positive influence on consumers' attachment to the brand (a), attitudinal loyalty toward the brand (b), and behavioral loyalty toward the brand (c).

Moreover, since this research integrates the links suggested by previous studies between consumers' attachement, attitudinal loyalty and behavioral loyalty (hypotheses 1-3), the following mediating effects must be posited:

H17. Consumers' attachment to the terroir SB mediates the relation between perceived store image and attitudinal loyalty toward the brand (a) and behavioral loyalty toward the brand (b).

H18. Consumers' attachment to the terroir SB and consumers' attitudinal loyalty toward this brand mediates the relation between perceived store image and behavioral loyalty toward the brand.

\subsection{The moderating role of consumers' profile}

Binninger (2007) indicated that consumers' buying profile of standard SBs (i.e., uninitiated, captive, unstable and engaged) influences the level of three variables relating to the relationship between consumers and these brands: satisfaction, attitude and loyalty. While the levels of satisfaction, attitude and loyalty of the uninitiated consumers are low, the levels of satisfaction, attitude and loyalty of the engaged consumers are high. The capitive consumers have high levels of attitude and loyalty but a low level of satisfaction and, on the contrary, the unstable consumers have a high level of satisfaction but low levels of attitude and loyalty.

Applied to terroir store brands, we could assume that the productrelated variables (perceived authenticity and perceived value of the terroir SB) would have a stronger impact on the relationship between consumers (attachment and loyalty) and these brands. Their regular purchasing behavior of these specific store brands could be explained by their convictions on the intrinsic qualities of terroir SBs. Conversely, occasional buyers would be more influenced by variables linked to the store and the retailer, compared to variables directly correlated with the products.

Consequently, we posit that:

H19. The predicted relationships will be stronger for regular buyers of the terroir store brand compared to occasional buyers of this brand.

Fig. 1 presents the model proposed in this research.

\section{Methodology}

\subsection{The chosen terroir store brand}

In this research, we decided to focus on the terroir store brand " $\mathrm{U}$
Saveurs" proposed by the retailer "Système U". This retailer shows its commitment to this offer directly by affixing its name on it in a store brand strategy.

Système $\mathrm{U}$ is a French cooperative of food retail merchants. At the end of 2016, the retailer's marketshare (in value) was $10.5 \%$, positioning it behind the other retailers: Leclerc (21.2\%), Carrefour (20.7\%), Intermarché (14.3\%), Casino (11.6\%) and Auchan (10.6\%). ${ }^{2}$

The study on the terroir store brand "U Saveurs" was relevant because:

- Système U is one the first retailers to have create a terroir store brand and, from a decade now, this retailer has been involved in developing its terroir product line;

- more than 150 french local companies work for the development and improvement of the 368 different products proposed by the terroir store brand "U Saveurs";

- these products have to demonstrate high levels of quality and must be produced by companies with an authentic know-how. These products are thus anchored in the terroir and French culinary traditions;

- Système U has actively been communicating (adversiting in and out its stores) about this line of products since July 2015.

\subsection{The data collection}

The data used to test the model proposed (see Fig. 1) were gathered via a survey administered to customers at a supermarket owned by the retailer "Système U".

For two weeks, we interviewed 372 customers, after their shopping trip, as they exited this supermarket with their purchases. Since we wanted to survey consumers who regularly buy the "U Saveurs" terroir SB and consumers who occasionally buy products of this brand (i.e., they purchase of less than one product every three months), only 268 consumers replied to our questionnaire face to face as they exited this supermarket.

After the suppression of 19 outliers, our final sample comprises a total of 249 customers (157 regular buyers and 92 occasional buyers of the terroir SB), $69.9 \%$ of which are female, $14.5 \%$ executives, $13.7 \%$ employees and $11.2 \%$ teachers, with the following age distribution: min $=17, \max =79$, mean $=37.47$ and standard deviation $=15.820$.

\subsection{The measurement scales used}

The perceived authenticity of the terroir SB was measured by three items inspired by the work of Camus (2004a). Three items derived from the studies of Diallo et al. (2013) were used to measure the perceived value of this terroir SB. Consumers' trust in the retailer was measured by four items proposed by Kaabachi (2015). Perceived image of the

\footnotetext{
${ }^{2}$ KantarWordpanel, P13, 2015.
} 
store was measured by five items drawn from the work of Diallo et al. (2013). Concerning the consequences of these four variables, consumer attachment to the terroir SB was measured by five items taken from the study of Lacœuilhe (2000). Attitudinal and behavioral loyalty toward the terroir SB were measured using a three-item scales based on the works of Cristau (2001), Terrasse (2003), Belaid and Lacœuilhe (2015) and Coelho do Vale et al. (2016).

\subsection{The statistical tool used}

In the research, we used partial least squares method (PLS) with a bootstrap procedure with 200 replications (Tenenhaus et al., 2005) to analyse the data collected. The PLS method was retained for this research because: 1) it does not require the variables to follow a multivariate normal distribution; 2) it lets work with small samples; 3 ) it lets treat models that include a large number of latent variables (Hair et al., 2012). The software used is XLSTAT 2016.

\section{Results}

\subsection{Test of the measurement model}

The confirmatory factor analyses performed validated the supposed one-dimensional factor structures of our constructs, consistent with previous studies. Multi-group analyses and permutation tests were done. For each loading and each path coefficient posited we performed a significance test on the difference between the values obtained for each subgroup (Chin and Dibbern, 2010). These analyses led us to conclude that there was partial invariance (i.e., out of the 26 differences calculated, three are significant at the $5 \%$ level) of the measures used for the two subsamples formed based on consumers' regular or occasional purchases of terroir SB. Further, the factor loadings, which were higher than 0.5 and statistically significant at the $1 \%$ level, are satisfactory (Table 1) for both subsamples.

We then used Jöreskog's rhô coefficients (Jöreskog, 1971) to evaluate the reliability of our measurement tools used for the two subsamples formed based on consumers' regular or occasional purchases of terroir SB. The coefficients calculated were satisfactory for both subsamples ( $>0.7$ ) (Table 2). Lastly, the approach proposed by Fornell and Larcker (1981) let us establish the convergent and discriminant validity (Table 3) of our measurement tools for the two subsamples formed based on consumers' buying profile of terroir SB (regular or occasional). The analyses thus confirmed the reliability and validity of the measurement tools used for both subsamples.

\subsection{Test of the structural equation model}

Following the tests of the measurement models, all the links of the research model proposed were tested for the two subsamples considered based on whether the consumers purchased the "U Saveurs" terroir SB products regularly or occasionally. The indices of fit provided by the multi-group analyses performed for external GoF (performance of measurement models) are, for regular and occasional buyers of terroir SB respectively, 0.969 and 0.967 , and 0.852 and 0.837 for internal GoF (performance of structural models). The fit of the measurement and structural models proposed is satisfactory. Examination of the values of the parameters and of their significance indicates causal relations between the constructs measured (Figs. 2 and 3).

\subsubsection{Consumer-terroir SB relationship: the role of attachment and loyalty}

Attachment to the terroir SB has a positive and significant impact on attitudinal loyalty of regular and occasional buyers (respectively Path Coefficient $(\mathrm{PC})=0.425, \mathrm{t}=4.600, \mathrm{p}<0.01$ and $\mathrm{PC}=0.251, \mathrm{t}=$ $2.128, \mathrm{p}<0.05)$. Hypothesis $\mathrm{H} 1$ is therefore affirmed by our data. This result spreads previous works that indicated a link between consumers' brand attachment and attitudinal loyalty toward the brand (Lacœuilhe,
2000; Thomson et al., 2005; Louis and Lombart, 2010; Julienne, 2013) by confirming this link for terroir store brand.

Attachment to terroir SB also has a positive and significant influence on the behavioral loyalty of regular and occasional buyers (respectively $\mathrm{PC}=0.345, \mathrm{t}=4.363, \mathrm{p}<0.01$ and $\mathrm{PC}=0.326, \mathrm{t}=3.871$, $\mathrm{p}<0.01$ ). Hypothesis $\mathrm{H} 2$ is therefore affirmed by our data. This result extends to terroir store brand the work of Mende et al. (2013) which suggested that consumer attachment to a brand is a determinant of future behavioral intentions toward the brand.

Then, as predicted by the pioneering work of Jacoby and Chesnut (1978), attitudinal loyalty of regular and occasional buyers to terroir SB has a positive and significant impact on their behavioral loyalty (respectively $\mathrm{PC}=0.390 . \mathrm{t}=6.326, \mathrm{p}<0.01$ and $\mathrm{PC}=0.274, \mathrm{t}=$ $3.448, \mathrm{p}<0.01$ ). Hypothesis H3 is therefore affirmed by our data.

These results relating to the consumer-terroir SB relationship first highlight that this type of store brand may generate attachment which would lead to attitudinal and behavioral loyalty toward it. A consumer attached to terroir SB wants to maintain his relationship with this brand. Then, these results point out that the attachment process, and the consequences of this concept (i.e., consumer's choice of the brand is fixed) highlighted by the literature (Thomson et al., 2005; Park et al., 2010), are validated for terroir store brand.

Finally, as suggested by Julienne (2013), attachment to the terroir SB has an indirect influence on the behavioral loyalty of regular and occasional buyers of this brand via attitudinal loyalty (Table 4). Attitudinal loyalty is therefore a partial mediating variable of the relationship between attachment and behavioral loyalty. Hypothesis H4 is therefore affirmed by our data.

\subsubsection{Impacts of the perceptions of the product: role of perceived} authenticity and perceived value of terroir $S B$

The present study shows that the perceived authenticity of terroir SB products has a positive and significant influence on the perceived value of this specific $\mathrm{SB}$, for both regular buyers $(\mathrm{PC}=0.479, \mathrm{t}=$ $5178, \mathrm{p}<0.01)$ and occasional buyers $(\mathrm{PC}=0.312, \mathrm{t}=4090$. $\mathrm{p}<0.01$ ). Hypothesis $\mathrm{H} 8$ is therefore affirmed by our data. The perceived authenticity of terroir SB products is therefore an antecedent of the perceived value of this SB. However, whereas it explains $23 \%$ of this variable for regular buyers, it explains only $9.7 \%$ for occasional buyers. This study thus confirms that other variables than those connected uniquely to attractiveness in terms of price, such as perceived authenticity of products, may also explain the perceived value of the terroir SB, as Diallo et al. (2013) assert. Nonetheless, more classic variables, linked to price or price/quality ratio, may play a more important role for occasional buyers, given the lower explained variance for this specific consumer profile. Thus, especially for regular buyers of terroir SB, the foundations of this brand's value are partially different from those of other store brands (economic and standard SBs). Consistent with its positioning, the perceived value of terroir store brand is fueled by a symbolic dimension represented by the concept of perceived authenticity. The occasional purchasers of terroir store brand seem however less sensitive to this symbolic facet.

Further, our findings indicate that two variables, namely perceived authenticity of products and perceived value of the terroir SB, are decisive in attachment to this SB among regular and occasional buyers. Perceived authenticity of terroir SB products has a positive and significant influence on attachment to this $\mathrm{SB}$ among regular buyers $\mathrm{PC}=$ $0.253, \mathrm{t}=3.496, \mathrm{p}<0.01)$ and occasional buyers $(\mathrm{PC}=0.229, \mathrm{t}=$ $2427, \mathrm{p}<0.05$ ). Similarly, the perceived value of terroir SB has a positive and significant influence on attachment to this $\mathrm{SB}$ among regular buyers $(\mathrm{PC}=0.411, \mathrm{t}=5621, \mathrm{p}<0.01)$ and occasional buyers $(\mathrm{PC}=$ 0.340. $\mathrm{t}=3080 . \mathrm{p}<0.01)$. Hypotheses H5a et H9a are therefore supported by our data. Perceived authenticity of terroir SB products and the perceived value of this SB explain $42.7 \%$ and $30.5 \%$ of attachment to the terroir SB among regular buyers and occasional buyers respectively. Further, the perceived authenticity of terroir SB products has an 
Table 1

Results of confirmatory factor analyses.

\begin{tabular}{|c|c|c|c|c|c|}
\hline \multirow[b]{2}{*}{ Constructs } & \multirow[b]{2}{*}{ Items } & \multicolumn{2}{|c|}{$\begin{array}{l}\text { Regular buyers } \\
\text { SB de terroir } \\
n=157\end{array}$} & \multicolumn{2}{|c|}{$\begin{array}{l}\text { Occasional buyers } \\
\text { SB de terroir } \\
\mathrm{n}=92\end{array}$} \\
\hline & & Loadings & $\mathbf{t}$ & Loadings & $\mathbf{t}$ \\
\hline \multirow{4}{*}{$\begin{array}{l}\text { Perceived authenticity of terroir SB } \\
\text { products }\end{array}$} & Concerning the products U SAVEURS, I THINK THAT ... & & & & \\
\hline & These products do not contain artificial ingredients & 0.888 & $12.889^{* * *}$ & 0.902 & $10.351^{* * *}$ \\
\hline & I know how these products are made & 0.585 & $4.670^{* * *}$ & 0.685 & $6.646^{* * *}$ \\
\hline & These products are made from only natural ingredients & 0.822 & $11.945^{* * *}$ & 0.858 & $9.949 * * *$ \\
\hline \multirow[t]{4}{*}{ Perceived value of terroir SB } & Concerning THE TERROIR BRAND U SAVEURS, I THINK THAT ... & & & & \\
\hline & $\begin{array}{l}\text { In most product categories offered in stores of the retailer } \mathrm{U} \text {, the } \mathrm{U} \text { Saveurs brand and its } \\
\text { products are the best choice }\end{array}$ & 0.829 & $6.507 * * *$ & 0.697 & $4.416^{* * *}$ \\
\hline & I like when the U Saveurs brand is available in the product category I'm looking for & 0.751 & $7.266 * * *$ & 0.717 & $4.136^{* * *}$ \\
\hline & In general, the U Saveurs brand signifies good quality products & 0.665 & $5.571 * * *$ & 0.830 & $6.065^{* * *}$ \\
\hline \multirow[t]{5}{*}{ Trust in the retailer } & CONCERNING THE RETAILER U, I THINK THAT ... & & & & \\
\hline & I can count on this retailer to keep its promises & 0.852 & $7.076^{* * *}$ & 0.788 & $7.318 * * *$ \\
\hline & I trust in the product quality sold at this retailer & 0.839 & $10.517^{* * *}$ & 0.846 & $6.990 * * *$ \\
\hline & This retailer tries to constantly meet customers' needs and expectations & 0.798 & $8.549 * * *$ & 0.734 & $4.092^{* * *}$ \\
\hline & I trust this retailer & 0.863 & $8.886^{* * *}$ & 0.856 & $6.248 * * *$ \\
\hline \multirow[t]{6}{*}{ Perceived image of the store } & CONCERNING MY USUAL STORE, I THINK THAT ... & & & & \\
\hline & The store offers a varied selection of products & 0.739 & $9.872^{* * *}$ & 0.763 & $5.138 * * *$ \\
\hline & This store has a good layout & 0.820 & $10.731^{* * *}$ & 0.829 & $6.903^{* * *}$ \\
\hline & The store offers high-quality products & 0.758 & $11.472^{* * *}$ & 0.581 & $2.995^{* * *}$ \\
\hline & The store is practical when I go shopping & 0.723 & $6.281 * * *$ & 0.712 & $3.911 * * *$ \\
\hline & The store has friendly staff (listen to customers) & 0.684 & $5.768 * * *$ & 0.723 & $4.077 * * *$ \\
\hline \multirow[t]{6}{*}{ Attachment to terroir SB } & CONCERNING THE TERROIR BRAND U SAVEURS, ... & & & & \\
\hline & I like this brand very much & 0.806 & $11.837^{* * *}$ & 0.845 & $11.344^{* * *}$ \\
\hline & I am very pleased to buy this brand & 0.794 & $11.324^{* * *}$ & 0.900 & $12.654 * * *$ \\
\hline & I'm very attached to this brand & 0.867 & $13.118^{* * *}$ & 0.830 & $12.112^{* * *}$ \\
\hline & I am very reassured when I buy this brand & 0.838 & $11.610^{* * *}$ & 0.857 & $13.303^{* * *}$ \\
\hline & I'm very attracted to this brand & 0.874 & $14.719^{* * *}$ & 0.692 & $8.565^{* * *}$ \\
\hline \multirow[t]{4}{*}{ Attitudinal loyalty to terroir SB } & CONCERNING THE TERROIR BRAND U SAVEURS, ... & & & & \\
\hline & $\begin{array}{l}\text { If I do not find the products of this brand at my U store, I wouldn't mind buying the } \\
\text { products of another brand instead (inverted item) }\end{array}$ & 0.819 & $7.149 * * *$ & 0.727 & $4.674^{* * *}$ \\
\hline & $\begin{array}{l}\text { Even if the prices of the products of this brand would increase, I would continue to buy } \\
\text { them }\end{array}$ & 0.566 & $4.678^{* * *}$ & 0.758 & $4.922^{* * *}$ \\
\hline & $\begin{array}{l}\text { If a brand other than U Saveurs would offer promotions on similar products, I wouldn't } \\
\text { mind buying the products of another brand instead (inverted item) }\end{array}$ & 0.742 & $5.773^{* * *}$ & 0.635 & $3.239 * * *$ \\
\hline \multirow[t]{4}{*}{ Behavioral loyalty to terroir SB } & CONCERNING THE TERROIR BRAND U SAVEURS, ... & & & & \\
\hline & When I go shopping, I often look for products of this brand & 0.808 & $11.847^{* * *}$ & 0.568 & $3.296^{* * *}$ \\
\hline & It is important for me to buy products of this brand & 0.816 & $14.113^{* * *}$ & 0.767 & $7.018 * * *$ \\
\hline & $\begin{array}{l}\text { When the products of the brand U Saveurs are not offered on the shelves of my store U, I } \\
\text { am disappointed }\end{array}$ & 0.859 & $11.660^{* * *}$ & 0.807 & $6.959 * * *$ \\
\hline
\end{tabular}

Note: *** Note: *** Coefficient significant. Student's $t$-test values greater than $|2.575|$ indicate parameters significant at $1 \%$.

Table 2

Reliability indices - Jöreskog's rhô coefficients.

\begin{tabular}{lll}
\hline Constructs & $\begin{array}{l}\text { Regular buyers } \\
\text { of terroir SB } \\
\mathbf{n}=\mathbf{1 5 7}\end{array}$ & $\begin{array}{l}\text { Occasional buyers of } \\
\text { terroir SB } \\
\mathbf{n}=\mathbf{9 2}\end{array}$ \\
\hline $\begin{array}{l}\text { Perceived authenticity of terroir SB } \\
\quad \text { products }\end{array}$ & 0.813 & 0.860 \\
$\begin{array}{l}\text { Perceived value of terroir SB } \\
\text { Trust in the retailer }\end{array}$ & 0.800 & 0.797 \\
Perceived image of the store & 0.905 & 0.883 \\
Attachment to terroir SB & 0.857 & 0.851 \\
Attitudinal loyalty to terroir SB & 0.923 & 0.916 \\
Behavioral loyalty to terroir SB & 0.748 & 0.752 \\
\hline
\end{tabular}

indirect influence on this variable via its perceived value (Table 4). Perceived value of the terroir SB is thus a partial mediating variable of the relationship between perceived authenticity of the terroir SB and consumers' attachment to the brand. Hypothesis H10a is affirmed by our data. These results complete the literature on terroir store brands by highlighting that terroir store brands may create attachment to them through perceived authenticity (Camus, 2004a) and perceived value
(Khan, 2010; Luarn and Lin, 2003; Lai, 2015), and that distinguishes these specific SBs from economic and standard SBs. Indeed, to our knowledge, previous works on store brands (Binniger, 2007; Belaid et al., 2016) have not demonstrated consumers' attachement to these brands. This attachment to terroir store brands is fueled by variables that symbolize the originality of their positioning and above all give meanings to their consumption, by contrast to other store brands or manufacturers' brands, on functional bases (good taste and traceability) or on dimensions linked to emotions and identity (nostalgia and selfcongruence).

Lastly, this study shows that for occasional buyers of the terroir SB, perceived authenticity of terroir SB products and the perceived value of this SB do not have a significant influence on the other variables of the relational chain considered in this research: attitudinal loyalty and behavioral loyalty to this SB. Hypotheses H5b, H5c and H9b, H9c are therefore not affirmed by our data for occasional buyers of terroir SB. These results are the opposite of those of previous works in the field of services marketing on the link between perceived value and consumers' loyalty (Chen and Hu, 2010; Cronin et al., 2000; Duman and Mattila, 2005; Yoon et al., 2010) and on the link between authenticity of terroir products and consumers' loyalty (Spielmann and Charters, 2013). For 
Table 3

Test of convergent and discriminant validity.

\begin{tabular}{|c|c|c|c|c|c|c|c|}
\hline & 1. & 2. & 3. & 4. & 5. & 6. & 7. \\
\hline \multicolumn{8}{|l|}{ Regular buyers of terroir SB $n=157$} \\
\hline 1. Perceived authenticity of terroir SB products & 0.602 & & & & & & \\
\hline 2. Perceived value of terroir SB & 0.055 & 0.564 & & & & & \\
\hline 3. Trust in the retailer & 0.067 & 0.200 & 0.702 & & & & \\
\hline 4. Perceived image of the store & 0.006 & 0.064 & 0.121 & 0.557 & & & \\
\hline 5. Attachment to terroir SB & 0.158 & 0.305 & 0.189 & 0.071 & 0.700 & & \\
\hline 6. Attitudinal loyalty to terroir SB & 0.056 & 0.045 & 0.042 & 0.000 & 0.150 & 0.513 & \\
\hline 7. Behavioral loyalty to terroir SB & 0.090 & 0.197 & 0.227 & 0.018 & 0.378 & 0.297 & 0.686 \\
\hline \multicolumn{8}{|l|}{$\begin{array}{l}\text { Occasional buyers of terroir SB } \\
\quad n=92\end{array}$} \\
\hline 1. Perceived authenticity of terroir SB products & 0.673 & & & & & & \\
\hline 2. Perceived value of terroir SB & 0.192 & 0.563 & & & & & \\
\hline 3. Trust in the retailer & 0.107 & 0.180 & 0.652 & & & & \\
\hline 4. Perceived image of the store & 0.000 & 0.040 & 0.294 & 0.527 & & & \\
\hline 5. Attachment to terroir SB & 0.184 & 0.219 & 0.073 & 0.006 & 0.685 & & \\
\hline 6. Attitudinal loyalty to terroir SB & 0.011 & 0.015 & 0.005 & 0.000 & 0.069 & 0.502 & \\
\hline 7. Behavioral loyalty to terroir SB & 0.174 & 0.314 & 0.084 & 0.015 & 0.371 & 0.185 & 0.521 \\
\hline
\end{tabular}

The convergent validities $\left(\rho_{v c}\right)$ are shown on the diagonal and the square of the correlations $\left(R_{i j}^{2}\right)$ appear below the diagonal.

regular buyers of the terroir SB, only the perceived value of this SB has a positive and significant impact on behavioral loyalty $(\mathrm{PC}=0.301, \mathrm{t}$ $=3.188, \mathrm{p}<0.01$ ). Consequently, for this specific consumer profile, only hypothesis $6 \mathrm{c}$ is supported by our data whereas hypotheses H5b, $\mathrm{H} 5 \mathrm{c}$ and $\mathrm{H} 9 \mathrm{~b}$ are refuted. Consequently, this research highlights the specificity of our field of research, terroir store brands, to the study of consumers' relationship to these very distinct brands (as pointed out in the conceptual framework) as well as the importance to consider consumers' buying profile (regular or occasional).

The influence of perceived authenticity of terroir SB products and the perceived value of this SB on attitudinal loyalty is indirect (Table 4) via attachment to this SB among regular and occasional buyers. Hypotheses H6a and H11a are therefore supported by our data. Similarly, the influence of the perceived authenticity of terroir SB products and the perceived value of this SB on behavioral loyalty is indirect (Table 4) via attachment (supporting H6b and H11b) or via attachment and attitudinal loyalty (supporting H7 and H12), among regular and occasional buyers of this SB. This research therefore highlights the central role of consumers' attachment to the terroir SB in order to advance along the relational chain posited in this research and thus maintain or reinforce attitudinal and behavioral loyalty toward this SB for regular and occasional buyers. In our specific field of research, terroir store brands, attachment is a total mediator of the relations studied except for the value-behavioral loyalty relationship for regular buyers of terroir SB, for whom it is only partial. As shown by various works on the consumer-brand relational chain (Thomson et al., 2005; Aurier and N'Goala, 2010), attachment is the starting point before developing loyalty. In the case of terroir store brands, retailers should therefore create first attachment before developing loyalty. This is especially true for occasional buyers of terroir store brands who do not have the habit to buy this brand.
4.2.3. Impacts of the perceptions of the store and of the retailer: role of perceived image of the store and trust in the retailer

Only trust in the retailer has a positive and significant impact on behavioral loyalty of regular buyers of terroir $\mathrm{SB}(\mathrm{PC}=0.205, \mathrm{t}=$ 3.097, $\mathrm{p}<0.01$ ). Hypothesis 13c, posited on the basis of the work of Coelho do Vale et al. (2016), is therefore affirmed by our data. By contrast, hypotheses H13a and H13b are not supported by our data, but only for this consumer profile, as well as hypotheses H14 and H15 relating to mediating effects. For this specific profile, the perceived image of the store has no impact on the three variables of the relational chain posited in this study, namely attachment, attitudinal loyalty and behavioral loyalty. Hypotheses H16a, H16b and H16c are therefore not affirmed by our data for this profile, as well as hypotheses H17 and H18 relating to mediating effect. Ultimately, for regular buyers of terroir SB, their perceived value, consumers' trust in the retailer and their attachment and attitudinal loyalty to this SB explain 58\% of their behavioral loyalty. For occasional buyers, only attachment and attitudinal loyalty to the SB explain $55.4 \%$ of their behavioral loyalty.

For occasional buyers of terroir SB, the perceived image of the store has a significant and positive impact $(\mathrm{PC}=0.238, \mathrm{t}=2023, \mathrm{p}<0.01$ ) on their attitudinal loyalty. Hypothesis 16b, posited on the basis of the work of Diallo et al. (2013), is therefore supported by our data. By contrast, hypotheses H16a and H16c are not supported by our data, but only for this consumer profile, as well as hypotheses H17 and H18 relating to mediating effects. For this specific profile, trust in the store has no impact on the three variables of the relational chain posited in this study: attachment, attitudinal loyalty and behavioral loyalty. Note that Lombart and Louis (2014) and Lombart et al. (2016) could not establish also a link between consumer trust and loyalty to the retailer. Hypotheses H13a, H13b and H13c are therefore not supported by our data for this profile, as well as hypotheses H14 and H15 relating to

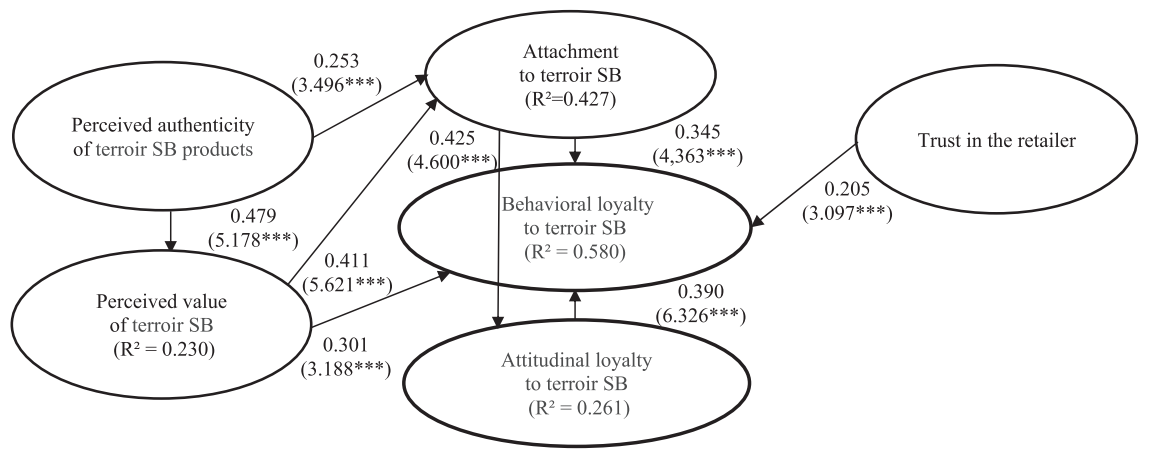

Fig. 2. Results of the structural equation model - Regular buyers of terroir SB $(n=157)$.

Note: $* * *$ Coefficient significant. Student's t test values greater than $|2.575|$ indicate parameters significant at $1 \%$. 


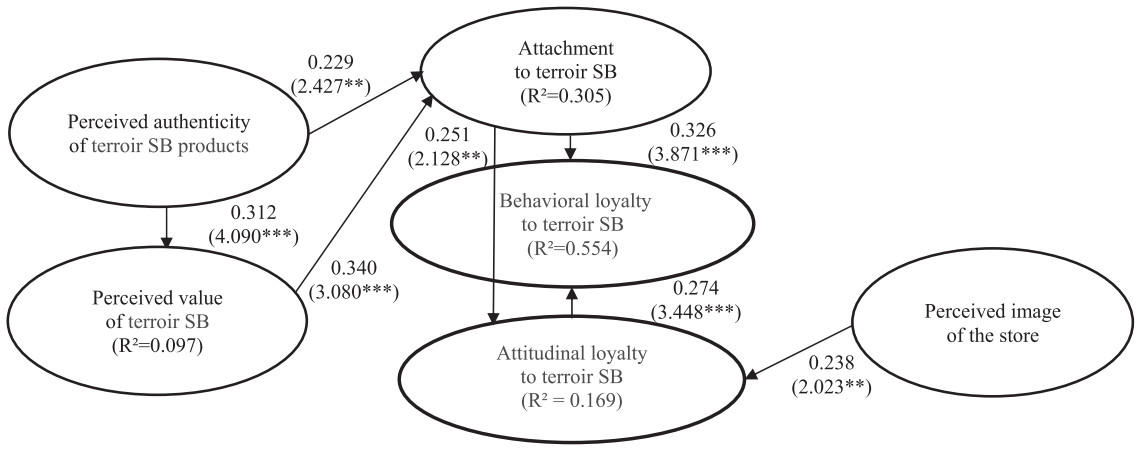

Fig. 3. Results of the structural equation model - Occasional buyers of terroir SB ( $\mathrm{n}=92)$.

Note: ***/** Coefficient significant. Student's $t$ test values greater than $|2.575 / 1.96|$ indicate parameters significant at $1 / 5 \%$.
Table 4

Indirect effects.

\begin{tabular}{|c|c|c|c|}
\hline $\begin{array}{l}\text { Regular buyers of terroir SB } n= \\
157\end{array}$ & $\begin{array}{l}\text { Attachment } \\
\text { to terroir SB }\end{array}$ & $\begin{array}{l}\text { Attitudinal } \\
\text { loyalty } \\
\text { to terroir SB }\end{array}$ & $\begin{array}{l}\text { Behavioral } \\
\text { loyalty } \\
\text { to terroir SB }\end{array}$ \\
\hline $\begin{array}{l}\text { Perceived authenticity of terroir SB } \\
\text { products }\end{array}$ & 0.128 & 0.149 & 0.222 \\
\hline Perceived value of terroir SB & & 0.175 & 0.198 \\
\hline Attachment to terroir SB & & & 0.166 \\
\hline $\begin{array}{l}\text { Occasional buyers of terroir SB } \mathbf{n} \\
\quad=92\end{array}$ & $\begin{array}{l}\text { Attachement } \\
\text { to terroir SB }\end{array}$ & $\begin{array}{l}\text { Attitudinal } \\
\text { loyalty } \\
\text { to terroir SB }\end{array}$ & $\begin{array}{l}\text { Behavioral } \\
\text { loyalty } \\
\text { to terroir SB }\end{array}$ \\
\hline $\begin{array}{l}\text { Perceived authenticity of terroir SB } \\
\text { products }\end{array}$ & 0.163 & 0.116 & 0.320 \\
\hline Perceived value of terroir SB & & 0.085 & 0.147 \\
\hline Attachement to terroir SB & & & 0.069 \\
\hline
\end{tabular}

mediating effects. Therefore, for occasional buyers of terroir SB, the perceived image of the store and attachment explain $16.9 \%$ of their attitudinal loyalty, compared with $26.1 \%$ for regular buyers with attachment only.

In essence, if trust in the retailer (Coelho do Vale et al., 2016) and perceived image of the store (Diallo et al., 2013) influence consumers' behavior toward standard store brands, it is not as systematic for terroir store brands and it depends on the consumers' profile (i.e., regular or occasional buyers of terroir SB). Moreover, the effects of these two variables on the relationship that occasional or regular customers maintain with terroir SBs are relatively weak compared to the effects of consumers' perceptions of the products sold by these brands. Whatever the type of buyers, the means that the retailers should use to develop a relationship between their consumers and their terroir store brands are more correlated to the products' characteristics of these brands than to the retailer or its stores. Even if this offer is endorsed directly or indirectly by the retailers, it is neither the trust in the retailer or store image that influence attachment and loyalty (and if so, weakly). It is indeed the characteristics of the terroir SB products that have an impact on consumers' relationship with this type of store brand. These results are different from findings of previous works on consumers' loyalty toward store brands which highlight the influence of store image but also the influence of its price image in this relationship (Garretson et al., 2002; Diallo et al., 2013). These differences in results underline that the success of terroir store brands has different determinants compared to other store brands (economic and standard SBs).

\subsubsection{Test of the moderating role of consumers' profile}

If at first glance, we observe higher coefficients for regular buyers of the terroir SB than for occasional buyers, for the various relations studied, the multi-group analysis and the permutation test conducted do not illustrate significant differences between the values obtained, for each relationship, between the two subgroups (Chin and Dibbern, 2010) except for three relationships: perceived value-behavioral loyalty (significant at the 5\% level), perceived image/attitudinal loyalty (significant at the $10 \%$ level) and trust in the retailer/behavioral loyalty (significant at the $10 \%$ level). In other words, apart from these three links, the study findings are valid for both regular and occasional buyers of terroir SB. Consequently, H19 which assumed that the predicted relationships in this study will be stronger for regular buyers of terroir store brands compared to occasional buyers is partially validated.

\section{Discussion}

\subsection{Theoretical and managerial contributions}

The research objectives were to examine consumers' relationship to terroir SB by integrating the combined effects of consumers' perceptions of the product, the store and the retailer, respectively, in this relationship. Accordingly, we demonstrated that the perceived authenticity of the terroir SB products and its perceived value represent major antecedents of the relational chain considered in this research via a centralizing variable of their impact, namely attachment to the terroir SB. Terroir SB and their products create attachment and thus play a role in building consumers' loyalty toward this brand. Attachment to the terroir SB can indeed maintain or reinforce the attitudinal and behavioral loyalty of regular and occasional buyers of this SB. This capacity to generate attachment provides at least a partial answer to how consumers perceive SBs, which researchers and practitioners have pondered for many years. However, not all SBs can claim to have the same status and relational model.

From a theoretical angle, this research provides a model highlighting the determinants of the relationship between consumers and terroir store brands and stresses the relative importance of these determinants according to their buyers' profile of terroir store brands (i.e., regular verus occasional).

After having describe the specific characteristics of terroir store brands, this study first points out the role of a particular specific antecedent, namely perceived authenticity of terroir SB products, in the development of the relationship between the consumers (occasional and regular buyers of terroir SBs) and these SBs. This variable is logically absent from the studies on the determinants of standard store brands. This study also pinpoints the role of the perceived value of terroir store brands in the development of the relationship between the consumers (occasional and regular buyers of terroir SBs) and these SBs. The distinction between terroir store brands and other store brands (economic and standard SBs) on intrinsic characteristics and on a value that is not only functional indicated their capacity to build loyalty to the point of sale. While most of the works on the links between the store brands and the point of sale have mainly studied the impact of the store on these brands (Liu and Wang, 2008; Diallo et al., 2013), an inverted relation can be posited. The communication campaign of the retailer Lidl in France (wich pogresses in terms of market share in this country) validates this inverted relation with, on the one hand, comparative ads between the standard store brand products of this retailer and manufacturers' brands products and, on the other hand, an increased emphasis of its terroir store brand in its communications and in stores. This 
retailer relies on its own brands (which represent $90 \%$ of its offer) to developed consumers' loyalty. Other retailers used their image in order to create a favorable attitude toward the brands they endorse (see Leclerc with the development of its store brand "Marque Repère").

Then, this study highlights that for regular buyers of terroir SB, trust in the retailer has a positive impact on their behavioral loyalty toward this brand. Trust in the retailer can thus be construed as a last form of reassurance before the product purchase. Consequently, the link established between the retailer and this specific buyer profile must be maintained by indicating to these consumers how terroir SB products are part of the retailer's responsible commitments toward the regions and the employment areas that they represent, and toward consumers by offering quality products that consistently exceed their expectations. For occasional buyers of terroir SB, the onus would be first on the store and the image that it conveys to play this role by concretely cultivating prerequisites for consumers in this field (variety of products offered, practicality of the store layout, friendliness of the sales staff, etc.) since store image as a positive impact on consumers' attitudinal loyalty to the terroir SB.

Lastly, this research points out the importance of attachment as a key to understand the relational chain of consumers/regular or occasional buyers of terroir SBs. Before being able to generate loyalty, be it attitudinal or behavioral, terroir SBs must create attachment. For this specific type of brand, whose positioning does not primarily rest on criteria such as price or price-quality ratio, the affective link created by the brand is a primordial factor in the construction of the relationship with consumers. To create this emotional link, the roots of attachment to the brand have to be considered.

From a managerial viewpoint, these results highlight the importance of information provided to consumers, both regular and occasional buyers, on terroir SB (place, manufacturing process and manufacturing entity - SME, for example - product composition, nutritional qualities of these products, etc.) via their packaging or all other forms of communication at the point of sale or outside the stores. Moreover, the communication of terroir store brands must include an identity dimension: nostalgia, attachment to the terroir, to the place, sharing of values. Through this sharing of values linked to the territory, terroir store brands can become an instrument of retailers' Corporate Social Responsibility policy. Système U has used different means to communicate on its terroir store brand "U Saveurs". This retailer has indeed used ads on TV, advertising posters, a dedicated flyer ... The purpose of these different means of communication is to inform consumers on the different benefits offered by this specific type of brand. The Casino has privileged the packaging to communicate on the origin of the products of its terroir store brand "Ça vient d'Ici" through geographical maps and with humor. The discovery of these products, and potentially of their producers, via special activities in stores, could also be a useful lever to stimulate or reinforce the interest of occasional and regular buyers of these terroir SBs and to help consumers (re)discover the organoleptic qualities of terroir products.

This study has also demonstrated the lack of impact of the retailer or store on the relational chain posited in the study. Rather, the main influence comes from terroir SB products and from their promotion in store. The fact that the food retailers that offer terroir SBs have fairly similar positioning does not contribute to favoring the role of the retailer or the brand. The French retailers are presently questioning the segmentation of their store brands' offer to distinguish themselves from the others. The development of more local brands, which offer the opportunity to a retailer and its stores to be perceived as closer to their consumers, could respond to this concern as well as the implementation of co-branding with local terroir brands.

\subsection{Limitations and future research avenues}

This study nonetheless has limitations that represent new research avenues. First, it was conducted on a convenience sample that, by definition, precludes national representativeness. Nonetheless, Diallo et al. (2013) show that age, gender, income, and family size do not affect the choice of SB. Further, some one-dimensional measures, retained because they are quicker to administer to consumers, may be expanded by considering multidimensional measures for concepts such as value in future studies. In a similar logic, purchasing behaviors related to terroir SB products were measured through purchase intentions and not actual purchases, which could be examined in future research. Lastly, other food retailers than "Système U" could be considered to confirm or refute the lack of impact of the retailer and the store on the relational chain posited in this research.

\section{References}

Ailawadi, K.L., Neslin, S.A., Gedenk, K., 2001. Pursuing the value conscious consumer: store brands versus national brand promotions. J. Mark. 65 (1), 71-89.

Ambroise, L., Brignier, J.-M., Mathews, C., 2010. Les Motivations cachées des consommateurs de marques d'enseigne: et si on parlait d'autre chose queue du rapport qualité-prix. Rev. Fr. Mark. 227 (2/5), 45-59.

Aurier, P., Fort, F., 2005. Effets de la région d'origine, du produit, de la marque et de leurs congruences, sur l'évaluation des consommateurs: application aux produits agroalimentaires. Rech. Appl. Mark. 20 (4), 29-52.

Aurier, P., Fort, F., Siriex, L., 2004. Les produits du terroir du point de vue des consommateurs: sources perçues et association au terroir. In: 20 ème Congrès International de l'Association Française du Marketing, Saint Malo, France, CD-Rom.

Aurier, P., N'Goala, G., 2010. The differing and mediating roles of trust and relationship commitment in service relationship maintenance and development. J. Acad. Mark. Sci. 38 (3), 303-325.

Babin, B.J., Darden, W.R., Griffin, M., 1994. Work and/or fun: measuring hedonic and utilitarian shopping value. J. Consum. Res. 4 (20), 644-656.

Ball, A.D., Tasaki, L.H., 1992. The role and measurement of attachment in consumer behavior. J. Consum. Psychol. 2 (1), 155-172.

Barham, E., 2003. Translating terroir: the global challenge of French AOC labeling. J. Rural Stud. 19 (1), 127-138.

Belaid, S., Lacœuilhe, J., 2015. Mesure de l'attitude à l'égard de la MDD: nouvelles perspectives. Rev. Fr. Mark. 253 (2-4), 41-53.

Belaid, S., Breton, P., Lacœuilhe, J., 2016. Repenser l'offre des MDD: le regard croisé des développeurs et des managers de rayon. Rev. Fr. Mark. 257 (3-4), 7-22.

Belk, R.W., 1988. Possessions and the extended self. J. Consum. Res. 2 (15), 139-168.

Belk, R.W., 1992. Attachment to possessions. In: Low et I Altman, S.M. (Ed.), Place Attachment: Human Behavior And Environment. Plenum Press, New York, pp. 37-62.

Beristain, J.J., Zorilla, P., 2011. The relationship between store image and store brand equity: a conceptual framework and evidence from hypermarkets. J. Retail. Consum. Serv. 18 (6), 562-574.

Beylier, R.P., Messeghem, K., Fort, F., 2012. Rôle des MDD de terroir dans la construction de la légitimité des distributeurs, le cas «Reflets de France». Décis. Mark. 66 (2), 35-46.

Bezes, C., 2013. Effect of channel congruence on a retailer's image. Int. J. Retail Distrib. Manag. 41 (4), 254-273.

Binninger, A.-S., 2007. Les fondements psychologiques et relationnels des marques de distributeurs dans la distribution alimentaire. Décis. Mark. 45 (1), 45-57.

Bloemer, J., de Ruyter, K., 1998. On the relationship between store image, store satisfaction and store loyalty. Eur. J. Mark. 32 (5-6), 499-513.

Bowlby, J., 1969. The making and breaking of affectional bonds. Tavistock, London.

Burton, S., Lichtenstein, D.R., Netemeyer, R.G., Garretson, J.A., 1998. A scale for measuring attitude toward private label products and an examination of its psychological and behavioral correlates. J. Acad. Mark. Sci. 26 (4), 293-306.

Camus, S., 2004a. Proposition d'échelle de mesure de l'authenticité perçue d'un produit alimentaire. Rech. Appl. Mark. 18 (4), 39-63.

Camus S., 2004b. Créer de l'authenticité au sein des points de vente. In: $17^{\text {ème }}$ Colloque Etienne Thil, La Rochelle, France, CD-Rom.

Castaldo, S., Perrini, F., Misani, N., Tencati, A., 2009. The missing link between corporate social responsibility and consumer trust: the case of fair trade products. J. Bus. Ethics 84 (1), 1-15.

Chaniotakis, I.E., Lymperopoulos, C., Soureli, M., 2009. A research model for consumers' intention of buying private label frozen vegetables. J. Food Mark. 15 (2), 152-163.

Charters, S., 2006. Wine and Society: The Social and Cultural Context of a Drink Butterworth-Heinemann, Oxford.

Charters, S., Spielmann, N., Babin, B.J., 2017. The nature and value of terroir products. Eur. J. Mark. 51 (4), 748-771.

Charton-Vachet, F., Lombart, C., 2015. New conceptual and operational approach to the link between individual and region: regional belonging. Rech. Appl. Mark. 30 (1), 50-75.

Chaudhuri, A., Holbrook, M.B., 2001. The chain of effects form brand trust and brand affect to brand performance: the role of brand loyalty. J. Mark. Res. 65 (2), 81-93.

Chin, W.W., Dibbern, J., 2010. An introduction to a permutation based procedure for multi-group PLS analysis: results of tests of differences on simulated data and a cross cultural analysis of the sourcing of information system services between Germany and the USA. In: Vinzi, V.E., Chin, W.W., Henseler et H Wang, J. (Eds.), Handbook of Partial Least Squares Concepts: Concepts, Methods and Applications. Springer Handbooks of Computational Statistics, New York, pp. 171-193. 
Chen, P.-T., Hu, H.-H., 2010. How determinant attributes of service quality influence customer-perceived value: an empirical investigation of the Australian coffee outle industry. Int. J. Contemp. Hosp. Manag. 22 (4), 535-551.

Coelho do Vale, R., Verga Matos, P., Caiado, J., 2016. The impact of private labels on consumer store loyalty: an integrative perspective. J. Retail. Consum. Serv. 28, 179-188.

Collins-Dodd, C., Lindley, T., 2003. Store brands and retail differentiation: the influence of store image and store brand attitude on store own brand perceptions. J. Retail. Consum. Serv. 10 (6), 345-352.

Cristau, C., 2001. Définition et mesure et modélisation de l'attachement à la marque avec deux composantes: la dépendance et l'amitié vis-à-vis d'une marque 3 IAE AixMarseille, Marseille.

Cronin, J.J., Brady, M.K., Hult, G.T.M., 2000. Assessing the effects of quality, value, and customer satisfaction on consumer behavioral intentions in service environments. J. Retail. 76 (2), 193-218.

Cross, R., Plantinga, A.J., Stavins, R.N., 2011. What is the value of terroir? In: American Economic Review: Papers \& Proceedings, vol. 101(3), pp. 152-156.

Debenedetti, A., 2014. Place attachment in commercial settings: a gift economy perspective. J. Consum. Res. 40 (5), 904-923.

Diallo, M.F., Chandon, J.L., Cliquet, G., Philippe, J., 2013. Factors influencing consumer behaviour towards store brands: evidence from the French market. Int. J. Retail Distrib. Manag. 41 (6), 422-441.

Duman, T., Mattila, A.S., 2005. The role of affective factors on perceived cruise vacation value. Tour. Manag. 26 (3), 311-323.

Dwyer, F.R., Schurr, P.H., Oh, S., 1987. Developing buyer-seller relationship. J. Mark. 51 (2), 11-27.

Fornell, C., Larcker, D.F., 1981. Evaluating structural equation models with unobservable variables and measurement error. J. Mark. Res. 18 (1), 39-50.

Fort, F., Fort, F., 2006. Alternatives marketing pour les produits de terroir. Rev. Fr. Gest. 32 (162), 145-159.

Fournier, S., 1998. Consumers and their brands: developing relationship theory in consumer research. J. Consum. Res. 24 (4), 343-373.

Garbarino, E., Johnson, M.S., 1999. The different roles of satisfaction, trust, and commitment in customer relationships. J. Mark. 63 (2), 70-87.

Garretson, J.A., Fisher, D., Burton, S., 2002. Antecedents of private label attitude and national brand promotion attitude: similarities and differences. J. Retail. 78 (2), 91-99.

Geyskens I., Steenkamp J., 1995. An investigation into joint effects of trust and interdependance on relationship commitment. In: Proceedings of the 24th EMAC Conference, Cergy, France, CD-Rom.

Gilliland, D.I., Bello, D.C., 2002. Two sides to attitudinal commitment: the effect of cal culative and loyalty commitment on enforcement mechanisms in distribution channels. J. Acad. Mark. Sci. 30 (1), 24-43.

Gundlach, G.T., 1995. The structure of commitment in exchange. J. Mark. 59 (1), 78-92.

Gurviez, P., Korchia, M., 2002. Proposition d'une échelle de mesure multidimensionnelle de la confiance dans la marque. Rech. Appl. Mark. 17 (3), 41-61.

Hair, J.F., Sarstedt, M., Ringle, C.M., Mena, J.A., 2012. An assessment of the use of partial least squares structural equation modeling in marketing research. J. Acad. Mark. Sci. 40 (3), 414-433.

Holbrook, M.B., Hirschman, E.C., 1982. The experiential aspects of consumption: consumer fantasies, feelings and fun. J. Consum. Res. 9 (2), 132-140.

Jacoby, J., Chesnut, R.W., 1978. Brand Loyalty: Measurement and Management. John Wiley \& Sons, New York.

Jara, M., 2009. Le capital-marque des marques de distributeurs: une approche conceptuelle. Rev. Fr. Mark. 221 (1), 47-61.

Jöreskog, K., 1971. Statistical analysis of sets of congeneric tests. Psychometrica 36 (2), 109-133.

Julienne, E., 2013. Le lien entre le consommateur et ses actes. Rech. Appl. Mark. 28 (1), 27-45.

Kaabachi, S., 2015. Pour une approche relationnelle de la fidélité du consommateur à l'enseigne: intégration des notions de valeur perçue, de satisfaction cumulée, de confiance et d'engagement: une application au domaine des enseignes de distribution alimentaires. Université Paris 1 Panthéon-Sorbonne, Paris.

Kaswengi, J., 2013. Les effets de l'image du magasin sur le capital marque: une étude à travers les circuits de magasin. Manag. Avenir 60, 102-119.

Keller, K.L., 1993. Conceptualizing, measuring and managing customer-based brand equity. J. Mark. 1 (57), 1-22.

Khan, N., 2010. Functional and relational value influence on commitment and future intention: the case of banking industry. The. J. Int. Social. Res. 3 (10), 376-391.

Kiesler, C.A., 1971. Commitment. In: Abelson, R.P. (Ed.), Theories of Cognitive Consistency: A Sourcebook. Ran McNally, Chicago, pp. 448-455.

Lacey, R., 2007. Relationship drivers of customer commitment. J. Mark. Theory Pract. 15 (4), 315-333.
Lai, Y.H., 2015. Enhance online purchase intentions: the role of perceived value, trust and commitment. J. Tour. Hosp. Manag. 3 (2), 89-99.

Lacœuilhe, J., 2000. L'attachement à la marque: proposition d'une échelle de mesure. Rech. Appl. Mark. 15 (4), 73-91.

Lenglet, F., 2014. Influence of terroir products meaning on consumer's expectations and likings. Food Qual. Prefer. 32, 264-270.

Lenglet, F., Kréziak, D., Lacroix, A., 2015. L’agrément du lieu fait-il vendre? La contribution des aménités à la valorisation des produits du terroir. Rev. Fr. Mark. 253 (3-4), 41-59.

Liu, T.C., Wang, C.Y., 2008. Factors affecting attitudes toward private labels and promoted brands. J. Mark. Manag. 24 (3-4), 283-298.

Lin, C.-P., Chen, S.-C., Chin, C.-K., Lee, W.-Y., 2011. Understanding purchase intention during product-harm crises: moderating effects of perceived corporate ability and corporate social responsibility. J. Bus. Ethics 102 (3), 455-471.

Lombart, C., Louis, D., 2014. A study of the impact of Corporate Social Responsibility and price image on retailer personality and consumers' reactions (satisfaction, trust and loyalty to the retailer). J. Retail. Consum. Serv. 21 (4), 630-642.

Lombart, C., Louis, D., Labbé-Pinlon, B., 2016. Price image consequences. J. Retail. Consum. Serv. 28 (1), 107-116.

Louis, D., Lombart, C., 2010. Impact of brand personality on three major relational consequences (trust, attachment and commitment to the brand). J. Product. Brand Manag. 19 (2), 114-130.

Luarn, P., Lin, H.-H., 2003. A customer loyalty model for E-service context. J. Electron. Commer. Res. 4 (4), 156-167.

Magnoni, F., 2016. The effects of downward line extension on brand trust and brand attachment. Rech. Appl. Mark. 31 (1), 2-25.

Mende, M., Bolton, R.N., Bitner, M.J., 2013. Decoding customer-firm relationships: how attachment styles help explain customers' preferences for closeness, repurchase intentions, and changes in relationship breadth. J. Mark. Res. 50 (1), 125-142.

Moorman, C., Zaltman, G., Deshpande, R., 1992. Relationships between providers and users of market research: the dynamics of trust within and between organizations. J. Mark. Res. 29 (3), 314-328.

Morgan, R.M., Hunt, S.D., 1994. The commitment-trust theory of relationship marketing. J. Mark. 58 (3), 20-38.

Park, C.W., Young, S.M., 1986. Consumer response to television commercials: the impact of involvement and background music on brand attitude formation. J. Mark. Res. 23 (1), 11-24.

Park, C.W., MacInnis, D.J., Priester, J., Eisingerich, A.B., Iacobucci, 2010. Brand attachment and brand attitude strength: conceptual and empirical differentiation of two critical equity drivers. J. Mark. 6 (74), 1-17.

Pivato, S., Misani, N., Tencati, A., 2008. The impact of corporate social responsibility on consumer trust: the case of organic food. Bus. Ethics.: Eur. Rev. 17 (1), 3-12.

Ramaroson A., Kaswengi J., 2013. Le capital marque des marques de distributeur: le rôle de l'image du magasin et l'effet modérateur des types de MDD. In: $29^{\text {ème }}$ Congrès International de l'Association Française du Marketing, La Rochelle, France, CD-Rom.

Richins, M.L., 1994. Valuing things: the public and private meanings of the self. J. Consum. Res. 21 (3), 504-521.

Spielmann, N., Charters, S., 2013. The dimensions of authenticity in terroir products. Int. J. Wine Bus. Res. 25 (4), 310-324.

Spielmann, N., Gélinas-Chebat, C., 2012. Terroir? That's not how I would describe it. Int. J. Wine Bus. Res. 24 (4), 254-270.

Stanaland, A.J.S., Lwin, M.O., Murphy, P.E., 2011. Consumer perceptions of the antecedents and consequences of corporate social responsibility. J. Bus. Ethics 102 (1), 47-55.

Tenenhaus, M., Esposito Vinzi, V., Chatelin, Y.M., Lauro, C., 2005. PLS path modeling. Comput. Stat. Data Anal. 48 (1), 159-205.

Terrasse C., 2003. Proposition et validation d'une échelle de l'engagement à la marque. In" $19^{\text {ème }}$ Congrès International de l'Association Française du Marketing, Tunis, Tunisie.

Terrasse, C., 2006. L'engagement envers la marque: proposition d'un modèle théorique et application à la comparaison de la fidélité aux marques nationales et aux marques de distributeurs. HEC, Paris.

Thomson, M., MacInnis, D.J., Park, W., 2005. The ties that bind: measuring the strength of consumer's emotional attachments to brands. J. Consum. Psychol. 15 (1), 77-91.

Vaudour, E., 2002. The quality of grapes and wine in relation to geography: notions of terroir at various scales. J. Wine Res. 13 (2), 117-141.

Wallendorf, M., Arnould, E.J., 1988. "My Favorite Things": a cross-cultural inquiry into object attachment, possessiveness, and social linkage. J. Consum. Res. 14 (4), 31-547.

Yoon, Y.S., Lee, J.S., Lee, C.K., 2010. Measuring festival quality and value affecting visitors' satisfaction and loyalty using a structural approach. Int. J. Hosp. Manag. 29 (2), 335-342. 